\title{
The sex ratio and testosterone levels in Nile tilapia immersed in different doses of $17 \alpha$-methyltestosterone
}

\section{Rasio kelamin dan kadar testosteron dalam tubuh ikan nila yang direndam $17 \alpha-$-metiltestosteron dengan dosis berbeda}

\author{
Muhammad Zairin Junior ${ }^{1 *}$, Muhammad Restya Naufal ${ }^{1}$, Mia Setiawati ${ }^{1}$, \\ Dian Hardianto ${ }^{2}$, Alimuddin ${ }^{1}$ \\ ${ }^{1}$ Departemen Budidaya Perairan, Fakultas Perikanan dan Ilmu Kelautan, Institut Pertanian Bogor \\ Jalan Agatis, Kampus IPB Dramaga, Bogor 16680 \\ ${ }^{2}$ Balai Besar Perikanan Budidaya Air Tawar, Sukabumi. \\ *E-mail: zairinmz@live.com
}

\begin{abstract}
Nile tilapia farming using monosex male population has been reported to improve the productivity by $10 \%$ compared to that of mix-sex culture. This study aimed to determine an immersion dose of $17 \alpha$-metiltestosterone (MT) that resulted in higher male percentage, growth, survival, and to measure testosterone level in the fish body. The experiment compared three MT immersion doses, namely: $0 ; 1.8$; and $5.4 \mathrm{mg} / \mathrm{L}$, each with three replications. Immersion was conducted to 14-days-old larvae for four hours, with a density of $100 \mathrm{fish} / \mathrm{L}$ of water. Testosterone levels in fish was measured using ELISA method, and sex identification was performed by histological method. The result showed that the percentage of male fish was the same in treatments $1.8 \mathrm{mg} / \mathrm{L}$ and $5.4 \mathrm{mg} / \mathrm{L}$, which were 53-65\% higher than that of the control without MT treatment. Fish growth and survival until day 56 post immersion were not significantly different amongst treatments. The results of ELISA analysis showed that the levels of testosterone in larvae just after immersion was similar in $1.8 \mathrm{mg} / \mathrm{L}$ and $5.4 \mathrm{mg} / \mathrm{L}$ treatments, which then drastically decreased on day 14 after immersion. On day 28 after immersion the levels of testosterone of the MT treatments were similar to that of the control, i.e. about $2 \mathrm{ng} / \mathrm{g}$. On day 71 the testosterone levels in sex reversed and normal males fish remained the same at about $0.3 \mathrm{ng} / \mathrm{g}(\mathrm{P}>0.05)$. By PCR method with specific primer, sex reversed and normal males could be distinguished. In conclusion, sex reversal by immersion at a dose of $1.8 \mathrm{mg} / \mathrm{L}$ can be considered as a standard protocol for Nile tilapia sex reversal. Testosterone level in the body of MT-treated fish could be reduced to the same level as the control in less than one month post immersion.
\end{abstract}

Keywords: sex reversal, 17 $\alpha$-methyltestosterone, testosterone levels, immersion, tilapia

\begin{abstract}
ABSTRAK
Budidaya ikan nila menggunakan sistem monoseks jantan telah dilaporkan dapat meningkatkan produktivitas hingga 10\%. Penelitian ini dilakukan menentukan dosis perendaman hormon $17 \alpha$-metiltestosteron (MT) yang menghasilkan rasio ikan jantan tertinggi, pertumbuhan, sintasan, dan mengukur kadar testosteron dalam tubuh ikan nila. Dosis hormon MT yang diuji adalah 0; 1,8; dan 5,4 mg/L. Setiap perlakuan dosis diberi tiga ulangan. Perendaman dilakukan selama empat jam, dengan jumlah larva (umur 14 hari pascatetas) 100 ekor dalam $1 \mathrm{~L}$ air. Hasil analisis histologi menunjukkan bahwa persentase ikan nila jantan adalah sama pada perlakuan $1,8 \mathrm{mg} / \mathrm{L}$ dan $5,4 \mathrm{mg} / \mathrm{L}$, dan 53-65\% lebih tinggi daripada kontrol tanpa direndam MT (54\% jantan). Dengan analisis ELISA, kadar testosteron dalam tubuh larva sesaat setelah perendaman MT dosis $1,8 \mathrm{mg} / \mathrm{L}$ dan $5,4 \mathrm{mg} / \mathrm{L}$ adalah sama, tetapi turun drastis pada hari ke-14 pascarendam, kemudian kadarnya menjadi relatif sama pada hari ke-28, yaitu 2 ng/g). Pertumbuhan bobot dan sintasan ikan sampai hari ke-56 adalah sama. Dengan menggunakan metode PCR, jantan fungsional dan jantan normal dapat dibedakan, dan pada hari ke-71 kadar testosteron ikan jantan fungsional dan jantan normal adalah sama, yakni $0,3 \mathrm{ng} / \mathrm{g}$ ikan $(\mathrm{P}>0,05)$. Dengan demikian disimpulkan bahwa MT dosis $1,8 \mathrm{mg} / \mathrm{L}$ dapat dijadikan standar untuk sex reversal ikan nila. Kadar testosteron dalam tubuh ikan perlakuan MT menjadi sama dengan kontrol kurang dari satu bulan pascarendam.
\end{abstract}

Kata kunci: sex reversal, $17 \alpha$-metiltestosteron, kadar testosteron, perendaman, ikan nila 


\section{INTRODUCTION}

Nile tilapia Oreochromis niloticus is a freshwater fish that has rapid growth, high survival, and sex dimorphism. Nonetheless, male tilapia is growing faster than that of the female (Srisakultiew \& Komonrat, 2013). Thus, the culture of male monosex tilapia potentially offers higher productivity than mixed-sex tilapia culture. The male monosex tilapia can be applied using sex reversal. This method successfully produced $91.6 \%$ of male tilapia through immersion of $17 \alpha$-methyltestosterone (MT) at $1.8 \mathrm{mg} / \mathrm{L}$ for four hours with twice immersion treatment. The survival rate of the treated fish can reach 91-100\%. Similarly, Artanto (2010) reported the immersion of $5.0 \mathrm{mg} / \mathrm{L}$ MT for $24 \mathrm{~h}$ resulted in $96.55 \%$ male tilapia with a survival level of $91.36 \%$. Lower dose and shorter treatment with only once soaking (Wassermann \& Afonso, 2003) could improve cost and time efficiency (Artanto, 2010). Therefore, in the present study, the effect of single immersion of MT at 1.8 and $5.4 \mathrm{mg} / \mathrm{L}$ for $4 \mathrm{~h}$ on the ratio of male sex tilapia was observed.

The use of MT on humans has been reported to have side effects, such as muscle damage (Hassan et al., 2009) and lower heart beating (Legros et al., 1999). Similarly, the testosterone hormone may influence the aggressiveness level of fish (Zairin et al., 2016). On the other hand, testosterone levels are used as an indicator to determine the gonadal maturity, reproductive capacity (Preston et al., 2012), and testicular differentiation phase of fish (Nakamura \& Nagahama, 1989). According to Ministerial Decree of Marine and Fisheries No: KEP.52/ MEN/ 2014, the use of $17 \alpha$-methyltestosterone is banned due to its potential harm related to food security and environmental concern. Nevertheless, the International Standards for Responsible Tilapia Aquaculture still allow the use of methyl and etiltestosteron (WWF, 2009). Lower MT immersion doses with shorter time usage are reported to have lower MT residue and shorter time removal. Therefore, this study was conducted to measure and determine, when the level of testosterone in the tilapia's body postimmersion in MT was similar to the control.

Various methods can be used to detect the hormone, such as chromatography-tandem mass spectrometry (Chu et al., 2006; Amarasinghe et al., 2012; Nishshanka et al., 2015) and labelling using a radioactive with H-MT (Curtis et al., 1991; Jhonstone, 1983). However, those methods require a longer time to perform (Liu et al., 2013). In this study, enzyme-linked immunosorbent assay (ELISA) method was applied. ELISA method has been successfully detected various kinds of medicine residues, such as furazolidone in fish (Jester et al., 2014), furaltadone metabolites in shrimp (Liu et al., 2013), and 19-Nortestosterone in animal tissues (Jiang et al., 2011). This study aimed to determine the MT immersion dose that allows the highest percentage of males, growth, and survival. Furthermore, the testosterone level of tilapia fish was also measured.

\section{MATERIALS AND METHODS}

\section{Procurement tilapia larvae}

Nile tilapia broodstocks, which consisted of 7 males and 14 females were used in the experiment. The weight of both male and female tilapia broodstock was $800 \mathrm{~g}$. The male broodstock was placed together in a concrete tanks $(4 \times 2 \times 0.5 \mathrm{~m})$ with female broodstock for spawning with a male and female ratio of 1:2. Spawning tanks were equipped with water flow systems $(10 \mathrm{~L} / \mathrm{min})$. The broodstock fish were naturally spawned in the tanks for 14 days.

The eggs were collected from the broodstock tank, and the same phases of eggs were selected for the further experiment. The eggs were rinsed with clean water until the dirt was disappeared. The eggs were laid on top of the substrate (hapa) then placed into the aquarium, which had been added with $2-5 \mathrm{mg} / \mathrm{L}$ of methylene blue as an anti-fungal agent. The aquarium was equipped with an aeration system to maintain high dissolved oxygen levels in the medium.

\section{Larvae treatment and rearing}

$17 \alpha$-methyltestosterone (MT) used in this study was a SIGMA product with a purity level of $\geq 97 \%$. The hormone immersion was performed using 14 days post-hatched (dph) larvae. Three hundred larvae per treatment were soaked in 3 L of MT solution at the different concentrations according to the treatments, i.e. $1.8 \mathrm{mg} / \mathrm{L}$ (treatment one) and $5.4 \mathrm{mg} / \mathrm{L}$ (treatment two), respectively for four hours of immersion period. As a control, the same amount of larvae was immersed in water previously added with 0.05 $\mathrm{mL} / \mathrm{L}$ of ethanol $90 \%$ (Bart \& Athauda, 2003). Each treatment consisted of three replicates. The immersion was conducted using a plastic bag filled with water at a volume of $12 \mathrm{~L}$ and pure oxygen at a volume of $9 \mathrm{~L}$. 
Following immersion, larvae were reared in a glass aquarium with a dimension of $100 \times 50 \times 40$ $\mathrm{cm}^{3}$, which was filled with $150 \mathrm{~L}$ of water for 56 days of experimental period. Silk worms were fed to the larvae starting at day-5 or after the larvae started to eat exogenous food. Furthermore, the fish were fed a commercial pellet until the end of the study. Thirty experimental fish from each replicate were randomly weighed on day-7, 14, 28 , and 56, respectively. The fish survival of all samples were calculated at the end of the study. Water temperature was measured daily using a thermometer. The dissolved oxygen and $\mathrm{pH}$ were measured using DO meter and $\mathrm{pH}$ meter, whereas ammonia nitrogen (TAN) was measured using the protocol described by APHA (2005).

\section{Identification of the sex ratio}

Histological methods with acetocarmine were performed for sex identification following the procedure described by Guererro and Shelton (1974). 40 fish from each replicate tank were dissected, and the gonads were taken to determine for the sex examination. The histological observation was performed under a microscope with the magnification of 40 .

\section{Identification of functional male fish}

Functional males (XX) were identified using polymerase chain reaction (PCR) using genomic DNA template extracted from the fish caudal fin. Isolation of genomic DNA was performed using a DNA purification kit with the procedure following the manufacturer's intruction. DNA pellet was dissolved using $20 \mathrm{~mL}$ of ion exchanged water (IEW) and used as DNA template for PCR analyses. PCR was performed using two sets of specific primers that can distinguish between functional and normal males, namely (5'-CCA ATA AAG GCC CTC TGA AC-3') and (5'GCA GTT ATT TGT GGT CAC TA-3'). The PCR program was set at $95^{\circ} \mathrm{C}$ of predenaturation for five min, 35 cycles of amplification with denaturation at $95{ }^{\circ} \mathrm{C}$ for $20 \mathrm{~s}$, annealing at 55 ${ }^{\circ} \mathrm{C}$ for $15 \mathrm{~s}$, and extension at $72{ }^{\circ} \mathrm{C}$ for $30 \mathrm{~s}$, and a final extension at $72{ }^{\circ} \mathrm{C}$ for $10 \mathrm{~min} .1 \mu \mathrm{L}$ of PCR amplification products were then supplied into $1 \%$ of agarose gel electrophoresis. Visualization of DNA bands using Gel Doc was performed with ultraviolet light.

\section{Extraction and measurement of testosterone levels}

Testosterone levels were measured using enzyme-linked immunosorbent assay (ELISA) method at $450 \mathrm{~nm}$ of wavelength which was done in the Freshwater Aquaculture Institute of Sukabumi. Testosterone was extracted using RIDASCREEN® kits following the manufacturer's instruction manual. Samples of 5 $\mathrm{g}$ of fish from each replicate were taken on day$7,14,28$, and 56 post immersion. The number of fish samples collected for each sampling time was 100, 20, 10, 5, and 2, respectively. Functional males were taken from $5.4 \mathrm{mg} / \mathrm{L}$ MT treatment. Normal males, which were taken from the control (without MT immersion) were sampled after sex identification using PCR on day-71.

\section{Data analysis}

Statistical analysis was performed using a statistical program SPSS 21. Growth, survival, and testosterone levels were analyzed using analyses of variance (ANOVA) test at $\mathrm{P}$ level of 0.05. Significant difference between the treatments were further assessed using a post hoc Duncan test. Changes in the levels of testosterone in fish body after MT immersion and PCR results were descriptively analysed.

\section{RESULTS AND DISCUSSION}

\section{Sex ratio of Nile tilapia}

The sex ratios of Nile tilapia in MT treatment groups are presented in Figure 1. The percentage of males in MT treatment groups, both at 1.8 $\mathrm{mg} / \mathrm{L}$ and $5.4 \mathrm{mg} / \mathrm{L}$ doses, were higher $(\mathrm{P}<0.05)$ compared to that of the control. Furthermore, the percentage of males in MT treatment of $1.8 \mathrm{mg} / \mathrm{L}$ was similar to that of the $5.4 \mathrm{mg} / \mathrm{L}(\mathrm{P}>0.05)$.

\section{Fish average body weight, daily growth rate (DGR) and survival rate}

Based on the results of the study (Table 1), the average body weight and SGR of tilapia were similar amongst the treatments $(\mathrm{P}>0.05)$. Moreover, MT treatment on the fish larvae did not affect the fish survival $(\mathrm{P}>0.05)$. The survival levels of tilapia until the end of the experiment (day-56) were high, which was ranged from 78.53 to $89.98 \%$.

\section{Testosterone levels and functional male identification}

Changes in testosterone levels in the MT treated fish are presented in Figure 2. Testosterone levels of MT treated fish on day-0 (H0) up to day7 (H7) were relatively similar between the dose 


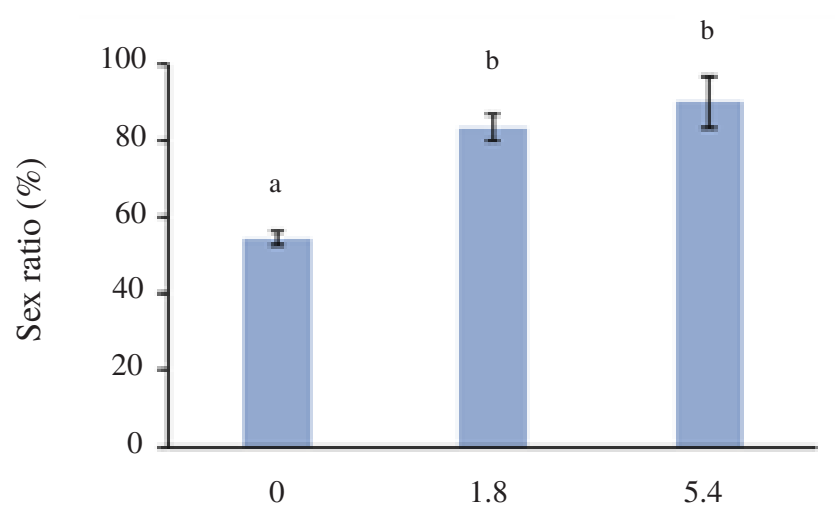

$17 \alpha$-methyltestosterone dose $(\mathrm{mg} / \mathrm{L})$

Figure 1. Male tilapia percentage after immersion with $17 \alpha$-methyltestosterone (MT) at a dose of $0(\mathrm{~K}), 1.8 \mathrm{mg} / \mathrm{L}$ and $5.4 \mathrm{mg} / \mathrm{L}$. Different letters in the bar indicates significant differences $(\mathrm{P}<0.05)$.

Table 1. Average body weight, daily growth rate (DGR), and the survival of tilapia immersed with hormone $17 \alpha$-methyltestosterone (MT) treatment at different doses

\begin{tabular}{cccc}
\hline MT treatments & Mean weight $(\mathrm{g})$ & DGR $(\% /$ hari $)$ & Survival rate $(\%)$ \\
\hline Control $(0 \mathrm{mg} / \mathrm{L})$ & $2.75 \pm 0.16 \mathrm{a}$ & $10.55 \pm 0.11 \mathrm{a}$ & $89.98 \pm 7.06 \mathrm{a}$ \\
$1.8 \mathrm{mg} / \mathrm{L}$ & $2.78 \pm 0.21 \mathrm{a}$ & $10.57 \pm 0.15 \mathrm{a}$ & $88.55 \pm 4.69 \mathrm{a}$ \\
$5.4 \mathrm{mg} / \mathrm{L}$ & $2.90 \pm 0.11 \mathrm{a}$ & $10.66 \pm 0.07 \mathrm{a}$ & $78.53 \pm 4.63 \mathrm{a}$ \\
\hline
\end{tabular}

Data is displayed in the form of mean \pm standard deviation of replicates. Different superscript letters in the same column indicate significant differences $(\mathrm{P}<0.05)$.

of $1.8 \mathrm{mg} / \mathrm{L}$ and $5.4 \mathrm{mg} / \mathrm{L}$, ranging from 12.3 to $12.8 \mathrm{ng} / \mathrm{g}$. Nonetheless, the levels were rapidly declined on day-14 after immersion and became equal to that of the control on day-28 after immersion onward (Figure 2).

Based on the result of male sex identification, DNA band sized between $550 \mathrm{bp}$ and $200 \mathrm{bp}$ (Figure 3). Based on PCR analyses, genetically male tilapia (XY) had DNA PCR product at 550 $\mathrm{bp}$, which was identified in the sample number 3 , 4, 5, 9, and 12 (Figure 3, marked by box dashed lines). Nine remaining samples were genetically female sex (XX). However, they were functionally male.

Testosterone levels of normal male and functional male measured on day-71 (Figure 4) were similar $(\mathrm{P}>0.05)$. Genetic factor of Nile tilapia has a significant role in sex determination (Caani et al., 2008). Nevertheless, sex differentiation of teleost fish can be affected by environmental factors, such as temperature, $\mathrm{pH}$, and pressure/stress (Baroiller \& D'Cotta, 2001). In addition, the ratio of males and females in many cases are significantly influenced by the differences in steroid hormone levels in their early development (Borg, 1994), such as the hormone 17 $\alpha$-methyltestosterone (Ajiboye et al., 2015). MT hormones are synthetic drugs (Miller, 2012) with the addition of $17 \alpha$ alkali group, which aimed to reduce oxidation in liver metabolism. It may increase the bioavailability up to $70 \%$ by slowing the metabolism rate (Lemke et al., 2012). The present study showed that the immersion of fish larvae in MT hormone at $5.4 \mathrm{mg} / \mathrm{L}$ and $1.8 \mathrm{mg} / \mathrm{L}$ dose on day- $14 \mathrm{dph}$ resulted in higher percentage of males than that of the control. The percentage of male tilapia following MT immersion at $1.8 \mathrm{mg} / \mathrm{L}$ and 5.4 $\mathrm{mg} / \mathrm{L}$ could reach $83 \%$ and $90 \%$, respectively, which was higher compared to the control (54\%). The age of larvae plays an important role in sex reversal. Straus et al. (2013), and Nakamura and Nagahama (1985) noted that sex differentiation occurs between day- 23 and 26 , immersing the larvae on day-14, i.e. when the sex was not yet differentiated, using the MT led to the success of masculinisation (Ogira et al., 2013). The success of masculinization of tilapia in the present study may be explained by the role of, MT that suppress aromatase expression, which has been 


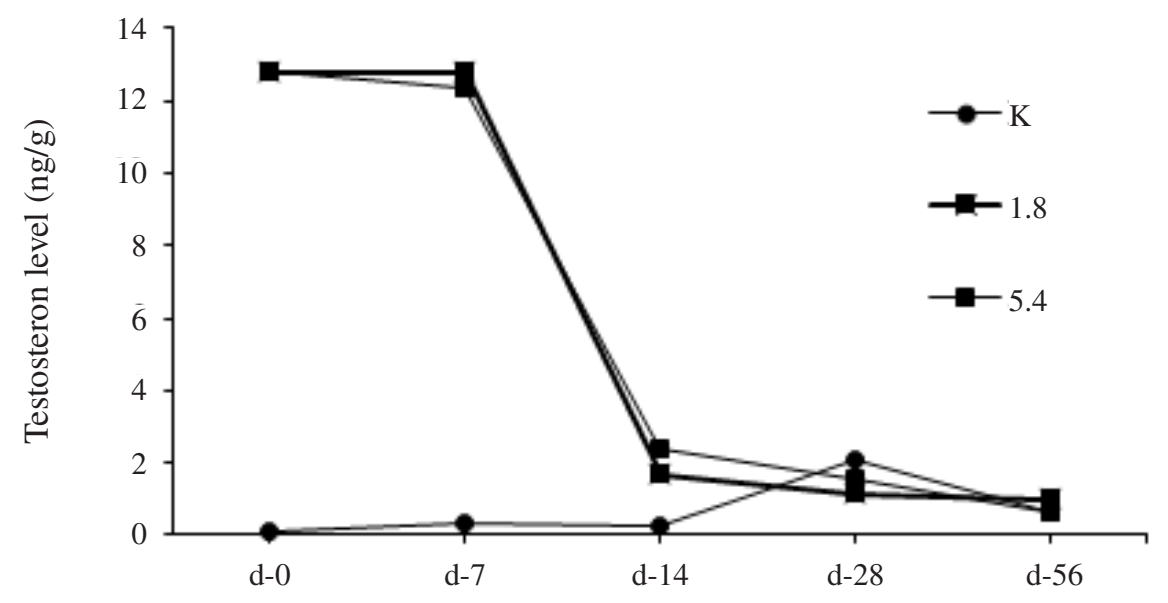

Observation period (day post-immersion)

Figure 2. Testosterone levels in tilapia (ng/g) previously immersed with $17 \alpha$-methyltestosterone (MT) at $0(\mathrm{~K}), 1.8$ $\mathrm{mg} / \mathrm{L}$ and $5.4 \mathrm{mg} / \mathrm{L}$ doses.

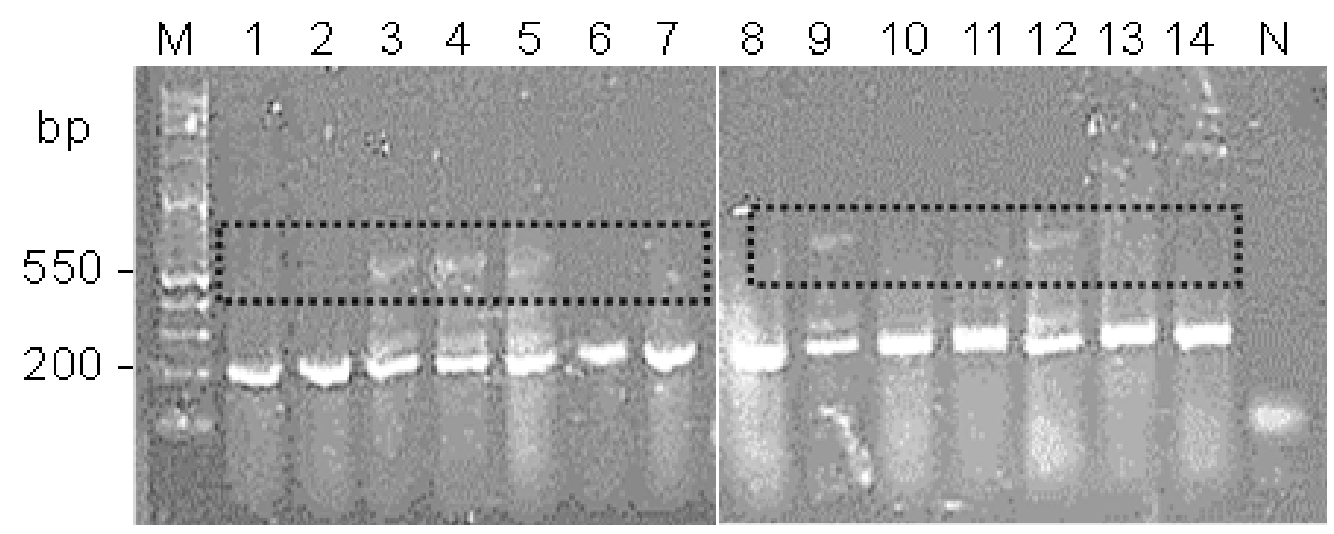

Figure 3. Identification of functional male tilapia (XX) using the PCR method. M: marker of fragment size 1-kb DNA ladder, numbers 1-14: number of fish samples, N: PCR products without DNA template. The digits in the left of the image are the size of the PCR fragment product. A dotted-line box is the DNA fragment into identifier XY male fish.

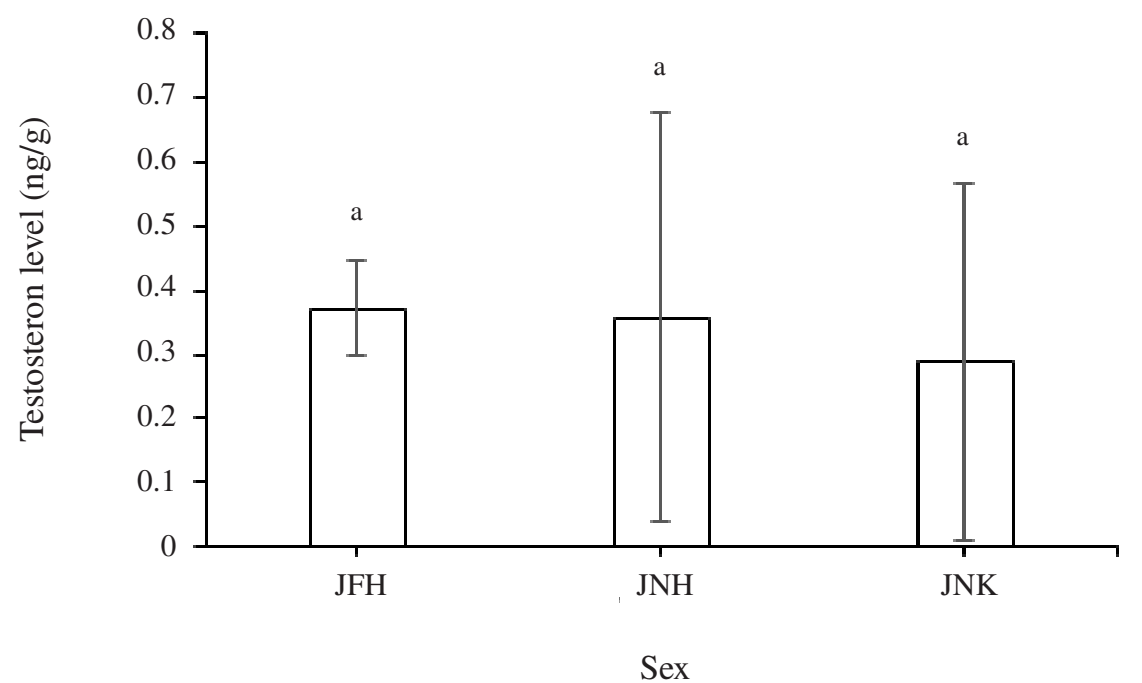

Figure 4. Testosterone levels in tilapia functional males (JFH), normal males (XY chromosomes) immersed with MT at $5.4 \mathrm{mg} / \mathrm{L}(\mathrm{JNH})$ and normal males from the control. 
identified to play a significant role in alterating of androgen hormones to oestrogens (Kitano et al., 2000). In sex differentiation, low expression of aromatase with high oestrogen levels leads to higher possibility for fish to become female.

Wassermann and Afonso (2003) reported that tilapia male percentage upon single immersion of MT at a dose of $1.8 \mathrm{~mL} / \mathrm{L}$ was $91.6 \%$, which was relatively similar to that obtained in this study $(83 \%)$. However, the percentage of male in the control in the present study (54\%) was lower than that reported by Wassermann and Afonso (2003) which was $71 \%$. This difference may be caused by the difference in water temperature at which the immersion was done (Baroiller \& D'Cotta, 2001). The temperature of MT treatment applied in the present study ranged from 24 to $27^{\circ} \mathrm{C}$, which was slightly lower than the temperature observed in the previous study $\left(28^{\circ} \mathrm{C}\right.$ to $\left.30^{\circ} \mathrm{C}\right)$ (Wassermann \& Afonso, 2003). The incubation temperature combined with MT treatment could affect sex ratio of tilapia (Afpriyaningrum et al., 2016). Furthermore, incubation temperature at $36{ }^{\circ} \mathrm{C}$ resulted in the higher percentage of male than that at $26{ }^{\circ} \mathrm{C}$ (Afpriyaningrum et al., 2016). This indicates that at higher temperature the absorption MT might be higher (Afpriyaningrum et al., 2016).

At the early stage of observation, the testosterone levels of fish immersed in $1.8 \mathrm{mg} / \mathrm{L}$ and $5.4 \mathrm{mg} / \mathrm{L}$ were higher than that of the control. This indicates that MT hormone was absorbed into the tilapia's body. However, it is also possible that there was a cross reaction with the kit used in this experiment because immediately after being immersed in MT, testosterone levels of the fish were higher as compared to control. ELISA Kit, which were used in the study highly allows cross-reactions between $17 \beta$-nortestosterone (10\%), 17 $\beta$-trenbolone (1\%), 17 $\beta$-estradiol, cortisol, corticosterone, and progesterone $(<0.1 \%)$. Consequently, it is possible that MT hormone detected with testosterone kit was actually a result of the cross-linking reaction. Additionally, MT hormone may changes into testosterone or other steroid hormones in the fish body before MT can be metabolised. Research on the transformation of MT hormone into glucuronides metabolites as an approach to detect residual metabolite of the hormone MT is still on going. Another possibility, MT hormone may affect the production of testosterone in the fish body. Several compounds and types of hormones may stimulate the production of testosterone in the body of fish such as HCG (Kagawa et al., 1984) and growth hormone (Pathak et al., 2015), which further can stimulate the production of testosterone. However, further research on whether MT hormone can directly or indirectly affect the levels of testosterone in the fish body is still needed.

The testosterone levels in all treatments using MT immersions began to decline significantly on day-14 after the treatment. Testosterone levels decreased by $80 \%$ were observed in all immersion doses $(1.8 \mathrm{mg} / \mathrm{L} ; 12.8 \mathrm{ng} / \mathrm{g}$ and $5.4 \mathrm{mg} / \mathrm{L} ; 12.33$ $\mathrm{ng} / \mathrm{g}$ ). The decreasing level of MT may be due to the fish metabolism (Thibaut \& Porte, 2004; Borg, 1994). Moreover, Curtis et al. (1991) reported that MT was not detected at 100 hours after immersion. Similarly, Johnstone et al. (1983) reported MT level of rainbow fish plummeted until 300 hours after oral administration of MT. In the present study, the levels of testosterone in both the MT treatments and control were getting similar $(2 \mathrm{ng} / \mathrm{g})$ on day- 28 .

Although tilapia may be consumed at smaller size as baby-fish, this is not the major aim of MT treatment, i.e. to produce more male fish that could grow into larger size. The present study showed that tilapia treated by MT is safe for consumption after day-28 of MT treatment as indicated by the similar testosterone levels in both MT treatment and the control on day-28.

Fourteen fish samples from the $5.4 \mathrm{mg} / \mathrm{L}$ MT treatment were kept observed until day-71 after immersion. The result showed that the average of testosterone levels of functional males XX $(0.333 \mathrm{ng} / \mathrm{g})$ and a normal male $\mathrm{XY}$ treatment $(0.338 \mathrm{ng} / \mathrm{g})$ were identical to normal male in the control $(0.29 \mathrm{ng} / \mathrm{g})$. It indicates that there was no MT residue found in the tilapia body. The results were lower than those reported by Nakamura and Nagahama (1989) on control fish at day-70 (0.87 $\mathrm{ng} / \mathrm{g}$ ), which may be due to different varieties of tilapia.

Previous studies reported that the growth of tilapia immersed in either 1.8 or $5.4 \mathrm{mg} / \mathrm{L}$ of MT was higher than that of the control. However, in this study, the growth of tilapia treated with MT and the control were not significantly different (Table 1). This may be due to the rearing condition in aquarium, which was not sufficient for optimal fish growth.. In contrast, Greisy and Gamal (2012) found that MT hormone orally administered to fish in the form of feed at $40 \mathrm{mg} / \mathrm{kg}$ demonstrates higher growth performance, whereas Rahman \& Christian (2007) reported that the presence of 
testosterone hormones in feed could lead to high muscle mass growth.

\section{CONCLUSION}

The immersion of tilapia larvae in $17 \alpha$-methyltestosterone (MT) hormone increased the percentage of males between $53-65 \%$ as compared to the control. The MT dosage of 1.8 $\mathrm{mg} / \mathrm{L}$ and $5.4 \mathrm{mg} / \mathrm{L}$ resulted in similar percentage of males, fish weight and survival. Testosterone levels in the fish in MT treatment were similar to that of the control on day-28 after immersion. Therefore, in term of cost efficiency, the dose of $1.8 \mathrm{mg} / \mathrm{L} \mathrm{MT}$ is recommended.

\section{ACKNOWLEDGEMENTS}

The research was partly funded by IPB Strategic Research Priority Number: 696/IT3.11/ PN/2016.

\section{REFERENCES}

Afpriyaningrum MD, Soelistyowati DT, Alimuddin, Zairin MJr, Setiawati M, Hardiantho D. 2016. Masculinization of Nile tilapia by larvae immersion at $36{ }^{\circ} \mathrm{C}$ and $17 \alpha$-methyltestosterone residual concentration in fish. Omni Akuatika 12: 106-113.

Ajiboye OO, Okonji AZ, Yakubu AF. 2015. Effect of testosterone-induced sex reversal on the sex ratio, growth enhancement and survival of Nile tilapia Oreochromis niloticus fed coppens and farm produced feed in a semi flow-through culture system. Fisheries and Aquaculture Journal 6: 1-7.

Amarasinghe K, Chu P, Evans E, Reimschuessel R, Hasbrouck N, Jayasuriya H.2012. Development of a fast screening and confirmatory method by liquid chromatography-quadrupole-timeof-flight mass spectrometry for glucuronideconjugated methyltestosterone metabolite in tilapia. Journal of Agricultural and Food Chemistry 60: 5084-5088.

[APHA] American Public Health Association. 2005. 4500-NH3 Nitrogen (Ammonia). In: Eaton AD, Clesceri LS, Rice EW, Greenberg AE (eds). Standard Methods for the Examination of Water and Wastewater, 21st ed. Washington DC, USA: APHA, American Water Works Association (AWWA) and Water Environment Federation (WEF).

Artanto. 2010. Pengaruh pemberian armotase inhibitor melalui perendaman larva terhadap keberhasilan sex reversal dan pertumbuhan ikan nila merah Oreochromis sp. [Skripsi]. Bogor: Institut Pertanian Bogor

Baroiller JF, Cotta HD. 2001. Environment and sex determination in farmed fish. Comparative Biochemistry and Physicology Part C 130: 399-409.

Borg B. 1994. Androgens in teleost fishes. Comparative Biochemistry and Physiology Part C: Pharmacology Toxicology and Endocrinology 109: 219-245.

Caani A, Lee BY, Zilberman N, Ozouf-Costaz C, Hulata G, Ron M, D'Hont A, Baroiller JF, Cotta HD, Penman DJ, Tomasino E, Coutanceau JP, Pepey E, Shirak A, Kocher TD. 2008. Genetics of sex determination in tilapiine species. Sexual Development 2: 4354.

Chu P, Lopez M, Serfling S, Gieseker C, Reimschuessel R. 2006. Determination of $17 \alpha$-methyltestosterone in muscle tissues of tilapia, rainbow trout, and salmon using liquid chromatography-tandem mass spectromtry. Journal Agricultural and Food Chemistry 54: 3193-3198.

Curtis LR, Diren FT, Hurley MD, Seim WK, Tubb RA. 1991. Disposition and elimination of $17 \alpha$-methyltestosterone in Nile tilapia Oreochromis niloticus. Aquaculture 99: 193201.

Fauzan AL, Soelistyowati DT, Zairin MJr, Hardiantho D, Setiawati M, Alimuddin. 2017. Aromatasegeneexpressionandmasculinization of Nile tilapia immersed in water $36{ }^{\circ} \mathrm{C}$ containing $17 \alpha$-methyltestosterone. Jurnal Akuakultur Indonesia (in press).

Greisy ZA, Gamal AEE. 2012. Monosex production of tilapia Oreochromis niloticus using different doses of $17 \alpha$-methyltestosterone with respect to the degree of sex stability after one year of treatment. Egyptian Journal of Aquatic Research 38: 59-66.

Guerrero RD, Shelton WL. 1974. An acetocarmine squash method for sexing juvenile fishes. The Progressive Fish-Culturist 36: $56-56$.

Hassan NA, Salem MF, Sayed MAEL. 2009. Doping and effects of anabolic androgenic steroids on the heart: histological, ultrastructural, and echocardiographic assessment in strength athletes. Human and Experimental Toxicology 28: 83-273.

Jester ELE, Abraham A, Wang Y, Said KRE, 
Plakas SM. 2014. Performance evaluation of commercial ELISA kits for screening of furazolidone and furaltadone residues in fish. Food Chemistry 145: 593-598.

Jiang J, Wang Z, Zhang H, Zhang X, Liu X, Wang, S. 2011. Monoclonal antibody-based ELISA and colloidal gold immunoassay for detecting 19-nortestosterone residue in animal tissues. Agricultural and Food Chemistry 59: 9763-9769.

Johnstone R, Macintosh DJ, Wright RS. 1983. Elimination of orally administered $17 \alpha$-methyltestosterone by Oreochromis mossambicus (tilapia) and Salmo gairdneri (rainbow trout) juveniles. Aquaculture 35: 249-257.

Kagawa H, Young G, Nagahama Y. 1984. In vitro estradiol-17 $\beta$ and testosterone production by ovarian follicles of the goldfish Carassius auratus. General and Comparative Endocrinology 54: 139-143.

Kitano T, Takamune K, Nagahama Y, Abe SI. 2000. Aromatase inhibitor and 17a-methyltestosterone cause sex-reversal from genetical females to phenotypic males and suppression of p450 aromatase gene expression in Japanese flounder Paralichthys olivaceus. Molecular Reproduction and Development 56: 1-5.

Legros T, Mcconnel D, Murry T, Edavettal M, Racey BLA, Shepherd RE, Burns AH. 1999. The effects of 17- $\alpha$ Methyltestosterone on myocardial function in vitro. Medical and Science in Sport and Exercise 32: 897-903.

Lemke T L, Williams DA, Roche VF, Zito SW. 2012. Foye's Principles of Medicinal Chemistry: $7^{\text {th }}$ ed. Wolters Kluwer Health Adis (ESP).

Liu Y, Jiang W, Chen Y, Xiao Y, Shi J, Qiao Y, Zhang H, Li T, Wang Q. 2013. A novel chemiluminescent ELISA for detecting furaltadone metabolite, 3-amino-5morpholinomethyl-2-oxazolidone (AMOZ) in fish, egg, honey and shrimp samples. Jurnal of Immunological Methods 395: 29-36.

Miller RL. 2012. The Encyclopedia of Addictive Drugs. London: Greenwood Press.

Nakamura M, Nagahama Y. 1985. Steroid producing cells during ovarian differentiation of the tilapia Sarotherodon niloticus. Development, Growth and Differentiation 27: 701-708.

Nakamura M, Nagahama Y. 1989. Differentiation and development of Leydig cells, and changes of testosterone levels during testicular differentiation in tilapia Oreochromis niloticus. Fish Physiology and Biochemistry 7: 211-219.

Nishshanka U, Chu P, Evans E, Reimschuessel R, Hasbrouck N, Amarasinghe K, Jayasuriya H. 2015. Tentative structural assignment of a glucuronide metabolite of methyltestosterone in tilapia bile by liquid chromatography quadrupole-time-of-flight mass spectrometry. Journal of Agricultural and Food Chemistry 63: 5753-5760.

Ogira PG, Liti D, Wanga J. 2013. Determination of age of Oreochromis niloticus fry after hatching for efficiency of 17- $\alpha$ methyltestosterone on sex reversal. International Journal of Science and Research 4: 657-662.

Pathak ND, Kumar P, Lal B. 2015. Endocrine regulation of testosterone production by Leydig cells in the catfish Clarias batrachus: Probable mediators of growth hormone. Animal Reproduction Science 154: 158-165.

Preston BT, Stevenson IR, Lincoln GA, Monfort SL, Pilkington JG, Wilson K. 2012. Testes size, testosterone production and reproductive behaviour in a natural mammalian mating system. Journal of Animal Ecology 81: 296305.

Rahman F, Christian HC. 2007. Non-classical actions of testosterone: an update. Trends in Endocrinology and Metabolism 18: 371-378.

Srisakultiew P, Kamonrat W. 2013. Immersion of $17 \alpha$-methyltestosterone dose and duration on tilapia masculinization. Journal of Fisheries Science 7: 302-308.

Straus DL, Bowker JD, Bowman MP, Carty DG, Mitchell AJ, Farmer BD, Ledbetter CK. 2013. Safety of feed treated with $17 \alpha$-methyltestosterone (17MT) to larval Nile tilapia. North American Journal of Aquaculture 75: 212-219.

Thibaut R, Porte C. 2004. Effects of endocrine disrupters on sex steroid synthesis and metabolism pathways in fish. Steroid Biochemistry and Molecular Biology 92: 485-494.

Wassermann GJ, Afonso LO. 2003. Sex reversal in Nile tilapia Oreochromis niloticus Linnaeus non-classical actions of testosterone: an update by androgen immersion. Aquaculture Research 34: 65-71.

[WWF] World Wildlife Fund. 2009. International standards for responsible tilapia aquaculture. Tilapia Aquaculture Dialogue. WWF. 
Junior MZ, Rahmawati NR, Maulana F, Alimuddin. 2016. Aggressiveness and growth of male Siamese fighting fish treated with different dose and duration of $17 \alpha$-methyltestosterone immersion. AACL Bioflux 9: 1364-1371. 